\title{
Lip repositioning with or without myotomy: a systematic review
}

\author{
Mohammadreza Talebi Ardakani ${ }^{1}$, Anahita Moscowchi ${ }^{1}$, Nasrin Keshavarz Valian ${ }^{1}$, Elham Zakerzadeh ${ }^{2}$ \\ ${ }^{1}$ Department of Periodontics, School of Dentistry, Shahid Beheshti University of Medical Sciences, Tehran, \\ ${ }^{2}$ Private Practice, Tehran, Iran
}

\begin{abstract}
J Korean Assoc Oral Maxillofac Surg 2021;47:3-14)
Excessive gingival display is an esthetic issue that is commonly managed by different procedures. Lip repositioning is a modality to address concerns of affected patients. The aim of this review was to investigate the scientific evidence on outcomes and long-term stability of lip repositioning surgery with or without myotomy. The electronic search was conducted in three databases: MEDLINE, Embase, and the Cochrane Library up to October 2019. No publication status, language, or time restrictions were applied. The electronic search was complemented by a manual search of the reference lists. Three hundred thirty-eight studies were screened by title, and 16 articles remained for data extraction. The included studies assessed the lip repositioning procedure in 144 patients aged between 15-59 years (134 females and 10 males). Based on the available data, lip repositioning with myotomy/muscle containment can be a successful treatment for minor discrepancies in gingival display in selected cases. However, further well-organized controlled clinical trials are recommended to derive a conclusion about the long-term stability compared with other alternatives.
\end{abstract}

Key words: Esthetics, Gingiva, Lip, Dental

[paper submitted 2020. 6. 7 / revised 2020. 8. 22 / accepted 2020. 11. 2]

\section{Introduction}

The increasing demand for an attractive smile in the last 40 years has resulted in development of various techniques to respond to patient concerns. Some individuals exhibit excessive gingival display (EGD), which is reported in $7 \%$ of in males and $14 \%$ of in females, and can impose esthetic issues $^{1}$. EGD can be classified into four distinct types: continuous band of EGD (type 1), which is the most common type; excessive display of the posterior gingiva (type 2); unilateral (type 3); and EGD in the anterior area (type 4$)^{2}$. In addition to a high smile line, which is prevalent among $10.57 \%$ to $38.9 \%$ of individuals ${ }^{1,3}$, factors including delayed tooth eruption or excessive tooth coverage with gingival tissue, inadequate up-

\footnotetext{
Anahita Moscowchi

Department of Periodontics, School of Dentistry, Shahid Beheshti University of Medical Sciences, Daneshjoo Blvd, Evin, Shahid Chamran Highway, Tehran 1983963113, Iran

TEL: +98-21-299-02314

E-mail:a.moscowchi@gmail.com

ORCID: https://orcid.org/0000-0003-1327-5014

(c) This is an open-access article distributed under the terms of the Creative Commons Attribution Non-Commercial License (http://creativecommons.org/ licenses/by-nc/4.0/), which permits unrestricted non-commercial use, distribution, and reproduction in any medium, provided the original work is properly cited. Copyright (C) 2021 The Korean Association of Oral and Maxillofacial Surgeons. All rights reserved.
}

per lip movement, upper lip length, and skeletal issues can contribute to this condition ${ }^{4}$.

In general, the underlying etiology of a gummy smile dictates the primary treatment approach. Such techniques include crown lengthening procedures ${ }^{5}$, orthodontic leveling of the gingival margins ${ }^{6}$, maxillary tooth intrusion ${ }^{7}$, lip repositioning ${ }^{8}$, orthognathic surgery ${ }^{9}$, and nonsurgical procedures such as administration of botulinum toxin $\mathrm{A}^{10}$.

Rubinstein and Kostianovsky ${ }^{11}$ in 1973 described lip repositioning surgery without muscular intervention. This technique is conducted to limit retraction of the upper lip elevator muscles through removal of a strip of mucosa from the maxillary buccal vestibule. More aggressive procedures to increase predictability have been reported with short-term follow-up periods including detachment of labial muscles ${ }^{12}$, applying a silicone spacer ${ }^{13}$, lip elongation with rhinoplasty ${ }^{14}$, and myotomy of the levator labii superioris along with frenectomy ${ }^{8}$. However, these techniques are not indicated in all cases suffering from gummy smile. Contraindications consist of severe vertical maxillary excess $(>8 \mathrm{~mm})$ and the presence of a minimal zone of attached gingiva, which can create difficulties in flap design, stabilization, and suturing ${ }^{15}$.

Regardless of its gain in popularity, lip repositioning procedures are mainly based on case reports and case series and do 
not seem to address any points beyond short-term improved outcomes. Furthermore, there has been greater emphasis on the importance of myotomy for long-term stability. Therefore, the aim of this study was to evaluate the available scientific evidence regarding the outcomes and long-term stability of lip repositioning surgery with or without myotomy.

\section{Methods}

A detailed protocol was developed and followed according to the PRISMA (Preferred Reporting Items for Systematic Reviews and Meta-Analyses) statement ${ }^{16}$.

\section{Focused questions}

PICO question (Participant, Intervention, Comparison, and Outcome):

(1) Participants (P): Patients with EGD

(2) Intervention (I): Lip repositioning surgery along with myotomy or muscle containment

(3) Comparison $(\mathrm{C})$ : Lip repositioning surgery alone

(4) Outcomes (O): Amount of improvement in gingival display and stability of the results

The literature was reviewed to answer the following questions:

(1) Does lip repositioning improve esthetics?

(2) Are the results achieved by these techniques stable?
(3) Is there any difference among the various techniques?

\section{Search strategy}

Two researchers (A.M. and N.K.V.) searched MEDLINE (through PubMed), Embase, and the Cochrane Library (including the Cochrane Central Register of Controlled Trials [CENTRAL]) up to October 2019. The search term 'lip repositioning' was utilized to retrieve all relevant studies. We did not limit our search strategy regarding study design, as doing so could have excluded pertinent publications ${ }^{17}$. No publication status, language, or time restrictions were applied. The electronic search was complemented by a manual search of the reference lists of all relevant articles.

\section{Inclusion criteria}

Clinical trials including case series and case reports were considered for inclusion. The Cochrane risk of bias tool for randomized trials ${ }^{18}$ and MINORS (methodological index for nonrandomized studies) were used ${ }^{19}$ to assess the quality of the studies included in this review.

\section{Exclusion criteria}

Studies with the following criteria were excluded from the final assessment:

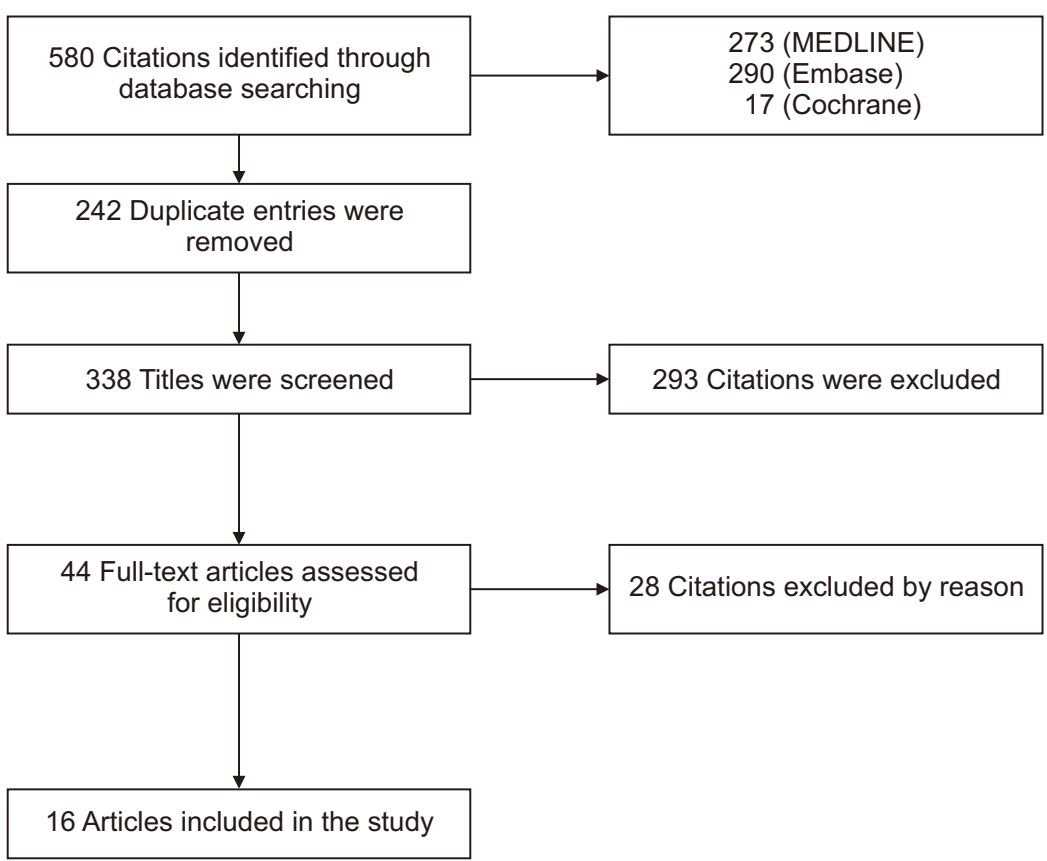

Fig. 1. Flowchart of the study selection process.

Mohammadreza Talebi Ardakani et al: Lip repositioning with or without myotomy: a systematic review. J Korean Assoc Oral Maxillofac Surg 2021 
(1) Follow-up duration less than 6 months

(2) Lack of data on preoperative and/or postoperative measurements

\section{Study selection and data synthesis}

Two authors (M.T.A. and A.M.) independently screened the titles and abstracts based on the inclusion criteria. Fulltext articles were obtained in case supplementary data were needed. The extracted data included patient information, preoperative and postoperative gingival display in millimeters at maximum smile, surgical technique, EGD etiology, followup period, and complications. Any disagreements during the process were resolved by discussion.

\section{Statistical analysis}

Standard methods were used to obtain the estimated overall effect size and the corresponding forest plot. All calculations were carried out using Comprehensive Meta-Analysis 2.2.064.

\section{Results}

The initial search yielded 580 articles: 273 articles through PubMed, 290 through Embase, and 17 articles through the Cochrane Library.(Fig. 1) Manual search resulted in no additional articles. Three hundred thirty-eight studies were screened by title (after elimination of duplicate entries) and 44 articles were considered for full-text assessment. Excluding 28 articles (Table 1) ${ }^{15,20-46}, 16$ studies remained for data extraction.(Fig. 1) Table $2^{8,47-61}$ shows the data extracted from these remaining studies.

The risk of bias assessment for non-comparative studies is presented in Table $3^{8,47,48,50,52-61}$. The risk of bias for one nonrandomized comparative study ${ }^{51}$ was estimated at 23 (of 24) based on the MINORS scoring criteria. The only randomized clinical trial ${ }^{49}$ was evaluated as "low risk" of bias based on the Cochrane risk of bias tool for randomized trials.

The included studies assessed lip repositioning procedures in 144 patients aged between 15-59 years (134 females and 10 males, not reported in one study with 14 patients $^{50}$ ). The most prevalent reported etiology was hypermobile upper lip ${ }^{47,48,50-53,55-57,59,60}$, followed by altered passive erup-

Table 1. Articles excluded following full-text assessment

\begin{tabular}{|c|c|c|c|c|c|c|}
\hline Study & $\begin{array}{l}\text { Follow-up less } \\
\text { than } 6 \text { months }\end{array}$ & $\begin{array}{l}\text { Lack of data on } \\
\text { preoperative and/ } \\
\text { or postoperative } \\
\text { measurements }\end{array}$ & $\begin{array}{c}\text { Lack of data } \\
\text { on etiology }\end{array}$ & $\begin{array}{c}\text { Conflicting } \\
\text { data }\end{array}$ & $\begin{array}{l}\text { Study } \\
\text { design }\end{array}$ & $\begin{array}{l}\text { No surgical } \\
\text { intervention }\end{array}$ \\
\hline Ramesh et al. $^{20}(2019)$ & & $*$ & & & & \\
\hline Foudah $^{21}(2019)$ & & * & & & & \\
\hline K et al. ${ }^{22}$ (2018) & & $*$ & $*$ & & & \\
\hline Faus-Matoses et al. $^{23}$ (2018) & $*$ & * & & & & \\
\hline Sharma et al. ${ }^{24}(2017)$ & $*$ & & $*$ & & & \\
\hline Sánchez et al. ${ }^{25}$ (2017) & $*$ & & & & & \\
\hline Littuma et al. $^{26}$ (2017) & & $*$ & & & & \\
\hline Khan et al. ${ }^{27}$ (2017) & & $*$ & & & & \\
\hline Gibson and Tatakis $^{28}$ (2017) & & $*$ & & & & \\
\hline Farista et al. $^{29}(2017)$ & & $*$ & & & & \\
\hline $\operatorname{Mahn}^{30}(2016)$ & & $*$ & & & & \\
\hline Aly and Hammouda ${ }^{31}$ (2016) & $*$ & & & & & \\
\hline Rao et al. ${ }^{32}(2015)$ & $*$ & & & & & \\
\hline Muthukumar et al. ${ }^{33}$ (2015) & & * & $*$ & & & \\
\hline Bhola et al. ${ }^{34}(2015)$ & & $*$ & & & & \\
\hline Storrer et al. ${ }^{35}$ (2014) & & $*$ & $*$ & & & \\
\hline Grover et al. ${ }^{36}(2014)$ & & $*$ & & & & \\
\hline Gaddale et al. ${ }^{37}$ (2014) & & $*$ & & & & \\
\hline Sheth et al. ${ }^{38}(2013)$ & $*$ & & & & & \\
\hline Humayun et al. ${ }^{39}$ (2010) & & $*$ & & & & \\
\hline Gupta et al. ${ }^{40}(2010)$ & & * & $*$ & & & \\
\hline Simon et al. ${ }^{15}$ (2007) & & $*$ & & & & \\
\hline Rosenblatt and Simon ${ }^{41}$ (2006) & & $*$ & $*$ & & & \\
\hline Ambrosio et al. ${ }^{42}(2018)$ & & & & $*$ & & \\
\hline Assenza et al. ${ }^{43}(2011)$ & & & & $*$ & & \\
\hline Ergezen et al. ${ }^{44}$ (2017) & & & & & $*$ & \\
\hline Mangano and Mangano $^{45}$ (2013) & & & & & & $*$ \\
\hline Polo $^{46}(2011)$ & & & & & & $*$ \\
\hline
\end{tabular}

Mohammadreza Talebi Ardakani et al: Lip repositioning with or without myotomy: a systematic review. J Korean Assoc Oral Maxillofac Surg 2021 


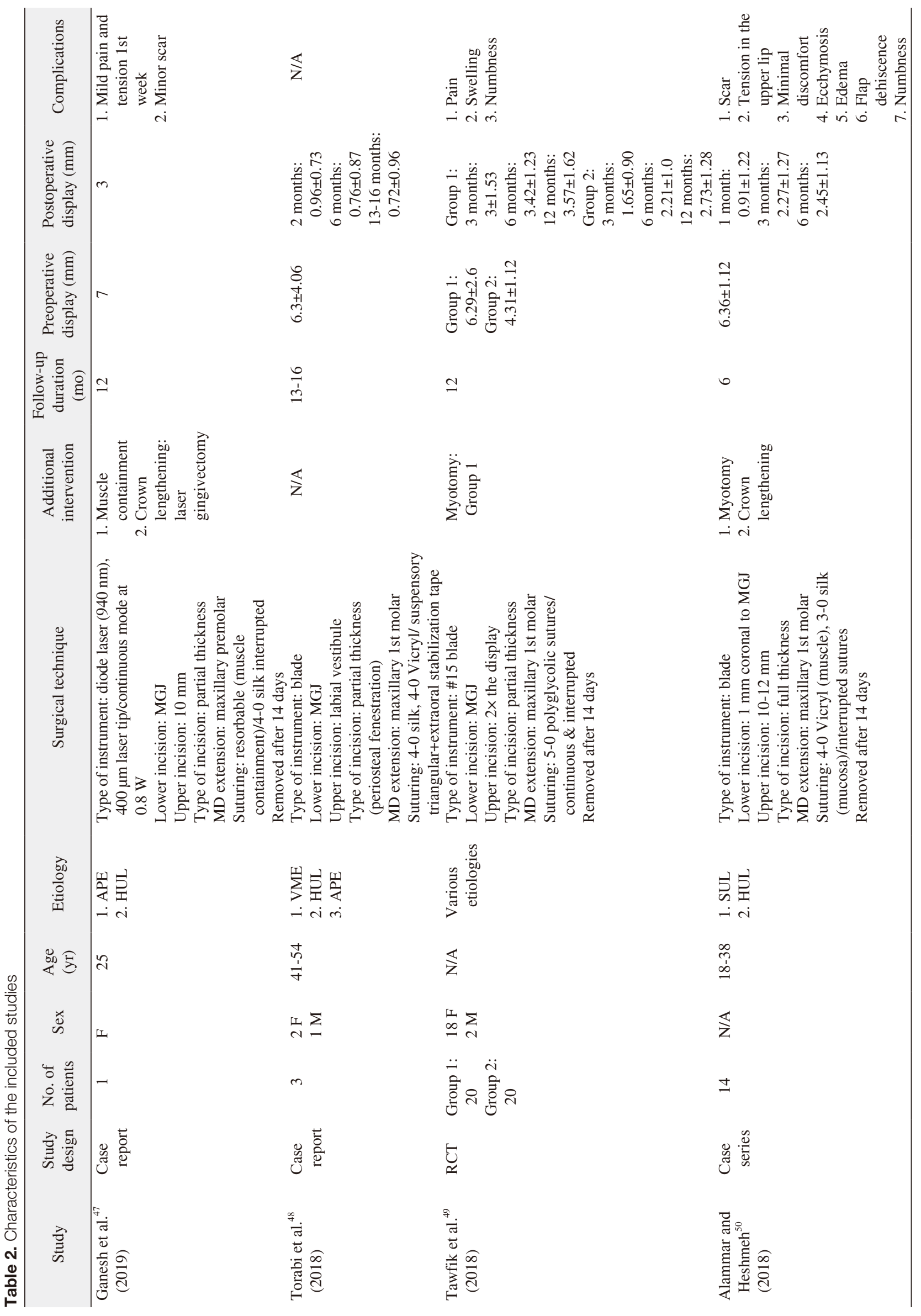




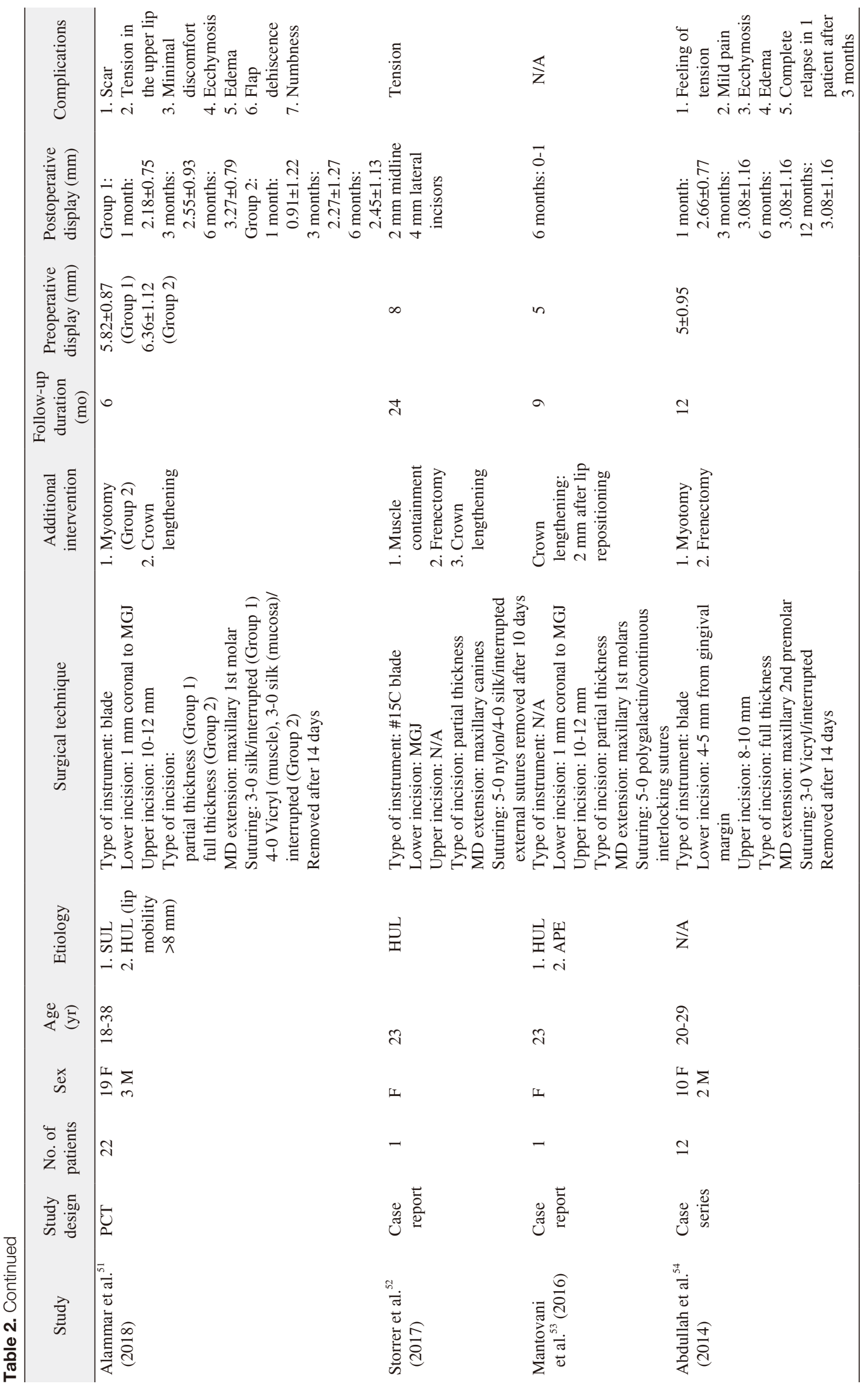




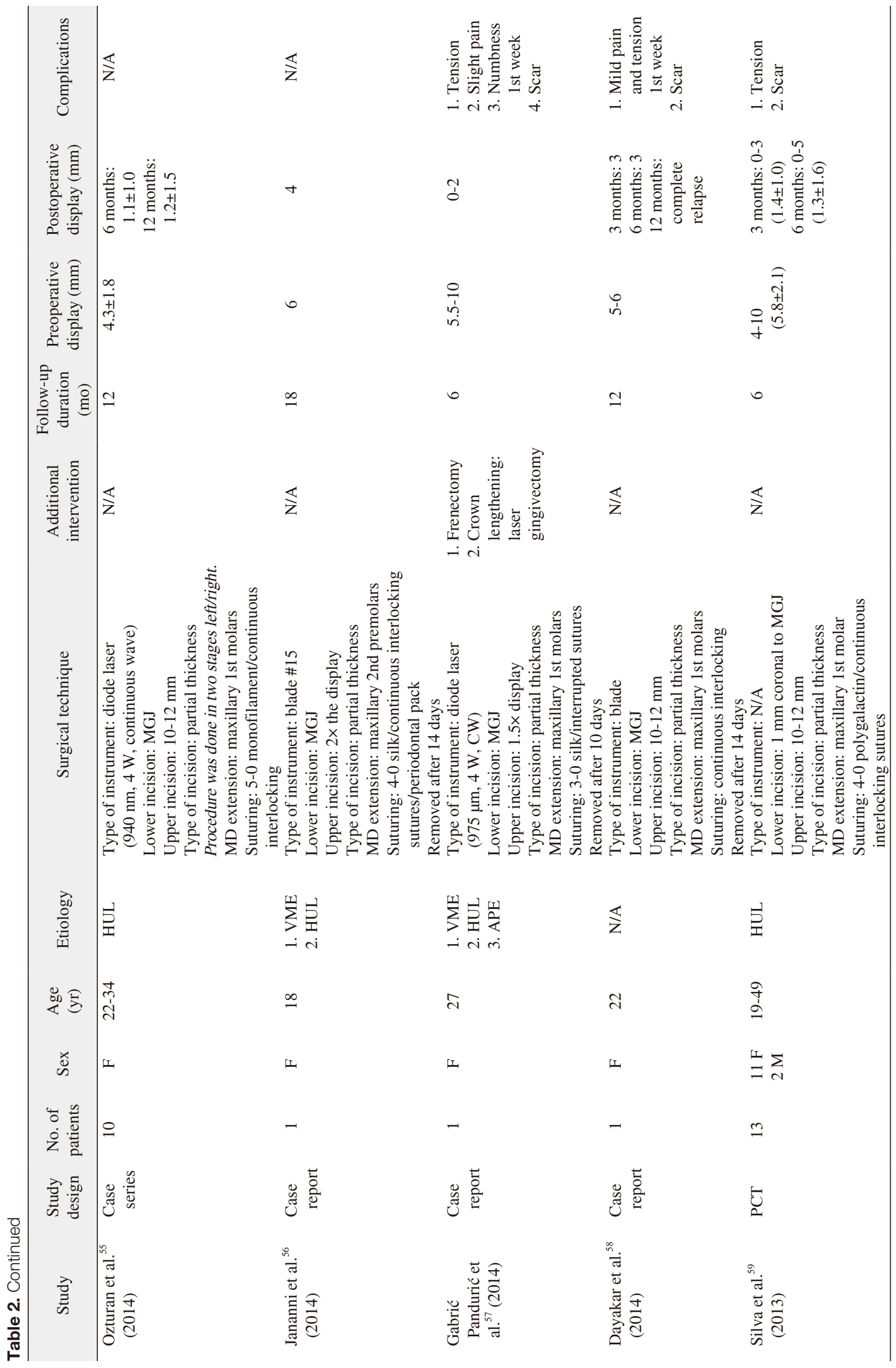




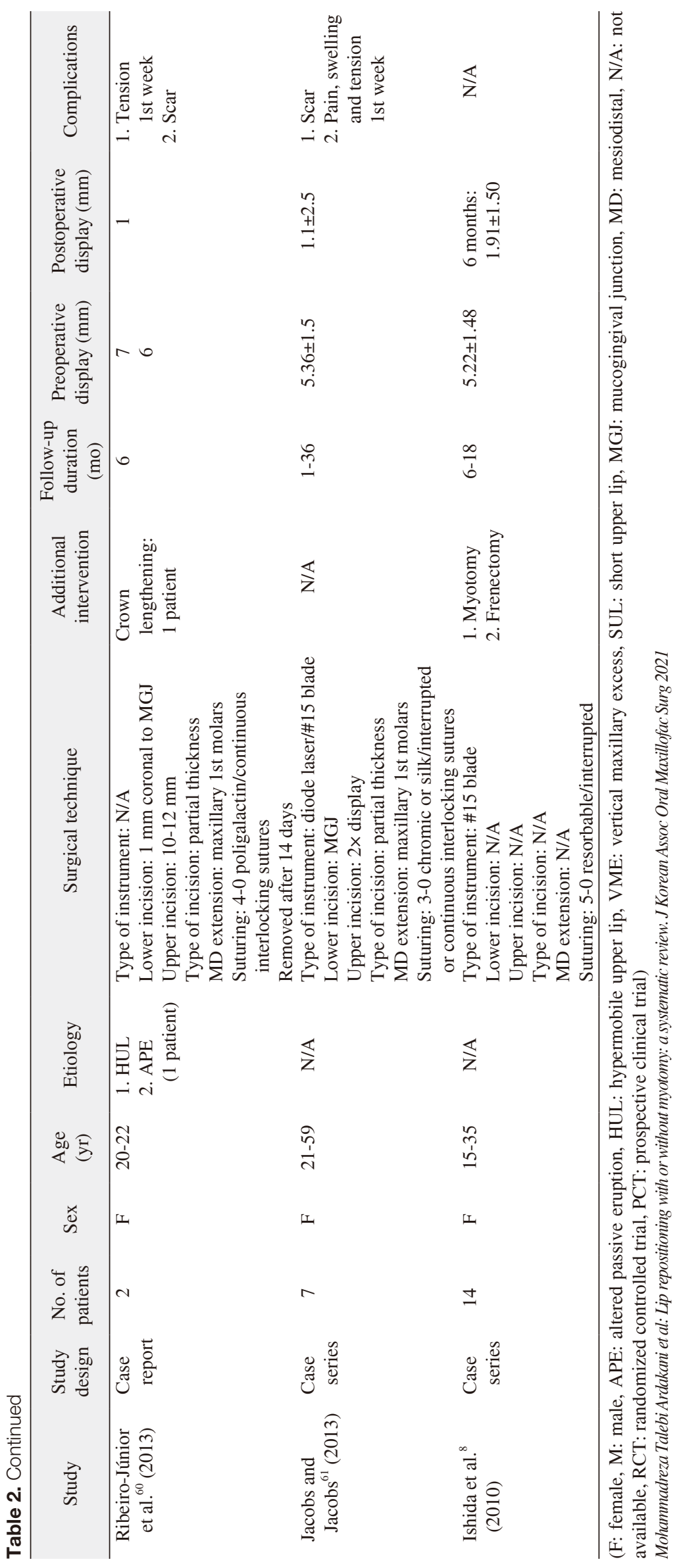


$\operatorname{tion}^{25,28,30,39,47,48,53,57,60}$, vertical maxillary excess ${ }^{48,56,57}$, and short upper $\operatorname{lip}^{50,51}$.

All but two studies ${ }^{50,54}$ used a partial-thickness flap. However, one comparative study reported better results with a full-thickness approach ${ }^{51}$. Some authors used additional interventions including crown lengthening ${ }^{47,50-53,57,60}$ and frenectomy ${ }^{8,23,33,37,52,54,57}$ to achieve more favorable results with higher stability. Alammar et al. ${ }^{51}$ mentioned two cases with complete relapse in their conventional surgical group. In addition, Dayakar et al. ${ }^{58}$ reported complete relapse after 12 months, but they did not report additional details.

Six studies provided sufficient data (sample size, mean, and either standard deviation or standard error) to contribute to estimation of the overall effect size for improvement after lip repositioning surgery.(Fig. 2) In five studies, myotomy was performed along with lip repositioning surgery ${ }^{8,49-51,54}$, while two investigations used sutures to confine the elevator muscles ${ }^{47,52}$. The analyzed data indicate an improvement of $1.76 \mathrm{~mm}$ (95\% confidence interval, 1.34-2.18 mm) with myotomy/muscle containment.(Fig. 3) Tawfik et al. ${ }^{49}$ reported that lip repositioning with myotomy resulted in greater improvement and higher patient satisfaction compared to that without myotomy, which was consistent with the results of another comparative study ${ }^{51}$.(Fig. 4)

\section{Discussion}

Among the procedures used to improve EGD, lip repositioning is a promising alternative. This procedure has been suggested for patients with minor discrepancies requesting a less invasive procedure compared with orthognathic surgery. It also satisfies patients who do not desire to undergo orthodontic therapy or botulinum toxin A administration. This study was conducted to evaluate the current literature regard-

Table 3. Quality assessment for non-comparative studies

\begin{tabular}{|c|c|c|c|c|c|c|c|c|c|}
\hline Study & Aim & Inclusion & $\begin{array}{c}\text { Data } \\
\text { collection }\end{array}$ & Endpoint & $\begin{array}{l}\text { Evaluation } \\
\text { (bias) }\end{array}$ & $\begin{array}{c}\text { Follow-up } \\
\text { period }\end{array}$ & $\begin{array}{l}\text { Loss to } \\
\text { follow-up }\end{array}$ & $\begin{array}{l}\text { Sample } \\
\text { size }\end{array}$ & $\begin{array}{l}\text { Total } \\
\text { score }\end{array}$ \\
\hline Ganesh et al. ${ }^{47}$ (2019) & 2 & 1 & 1 & 2 & 1 & 2 & 2 & 0 & 11 \\
\hline Torabi et al. ${ }^{48}(2018)$ & 1 & 2 & 1 & 2 & 2 & 2 & 2 & 1 & 13 \\
\hline Alammar and Heshmeh ${ }^{50}$ (2018) & 2 & 2 & 2 & 2 & 1 & 1 & 2 & 1 & 13 \\
\hline Storrer et al. ${ }^{52}(2017)$ & 1 & 1 & 1 & 1 & 1 & 1 & 2 & 0 & 8 \\
\hline Mantovani et al. ${ }^{53}$ (2016) & 2 & 1 & 1 & 1 & 0 & 1 & 2 & 0 & 8 \\
\hline Abdullah et al. ${ }^{54}(2014)$ & 2 & 2 & 2 & 2 & 2 & 2 & 2 & 1 & 15 \\
\hline Ozturan et al. ${ }^{55}$ (2014) & 2 & 2 & 2 & 2 & 2 & 2 & 2 & 1 & 15 \\
\hline Jananni et al. ${ }^{56}(2014)$ & 0 & 1 & 1 & 1 & 1 & 2 & 2 & 0 & 8 \\
\hline Gabrić Pandurić et al. ${ }^{57}$ (2014) & 2 & 1 & 2 & 2 & 2 & 2 & 2 & 0 & 13 \\
\hline Dayakar et al. $^{58}(2014)$ & 1 & 1 & 1 & 1 & 1 & 2 & 2 & 0 & 9 \\
\hline Silva et al. ${ }^{59}(2013)$ & 2 & 2 & 2 & 2 & 2 & 1 & 2 & 1 & 14 \\
\hline Ribeiro-Júnior et al. ${ }^{60}$ (2013) & 2 & 1 & 1 & 1 & 1 & 1 & 2 & 1 & 10 \\
\hline Jacobs and Jacobs $^{61}$ (2013) & 2 & 2 & 2 & 2 & 2 & 2 & 2 & 1 & 15 \\
\hline Ishida et al. ${ }^{8}(2010)$ & 2 & 2 & 2 & 2 & 2 & 2 & 2 & 1 & 15 \\
\hline
\end{tabular}

The items are scored 0 (not reported), 1 (reported but inadequate), or 2 (reported and adequate). The ideal score is 16 for non-comparative studies and 24 for comparative studies.

Mohammadreza Talebi Ardakani et al: Lip repositioning with or without myotomy: a systematic review. J Korean Assoc Oral Maxillofac Surg 2021

\section{Study name}

Torabi et al. ${ }^{48}(2018)$

Tawfik et al. ${ }^{49}(2018)$

Alammar et al. ${ }^{51}(2018)$

Ozturan et al. ${ }^{55}(2014)$

Silva et al. ${ }^{59}(2013)$

Jacobs and Jacobs ${ }^{61}(2013)$

$\begin{array}{cc}\begin{array}{c}\text { Std diff } \\ \text { in means }\end{array} & \begin{array}{c}\text { Standard } \\ \text { error }\end{array} \\ 1.508 & 0.844 \\ 1.875 & 0.371 \\ 3.062 & 0.719 \\ 2.049 & 0.557 \\ 2.368 & 0.541 \\ 1.955 & 0.645 \\ 2.090 & 0.226\end{array}$

\section{Statistics for each study}

$\begin{array}{crc}\text { Variance } & \begin{array}{c}\text { Lower } \\ \text { limit }\end{array} & \begin{array}{c}\text { Upper } \\ \text { limit }\end{array} \\ 0.712 & -0.146 & 3.163 \\ 0.138 & 1.147 & 2.603 \\ 0.517 & 1.652 & 4.471 \\ 0.310 & 0.958 & 3.140 \\ 0.293 & 1.308 & 3.429 \\ 0.416 & 0.691 & 3.218 \\ 0.051 & 1.648 & 2.532\end{array}$

$$
\begin{gathered}
\text { Z-value } \\
1.787 \\
5.050 \\
4.258 \\
3.680 \\
4.378 \\
3.031 \\
9.261
\end{gathered}
$$

Std diff in means and $95 \% \mathrm{Cl}$

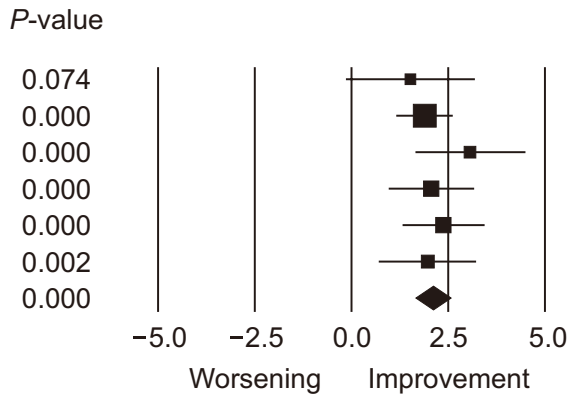

Fig. 2. Forest plot of effect size for lip repositioning without myotomy/muscle containment after 6 months. (Std diff: standard difference, Cl: confidence interval)

Mohammadreza Talebi Ardakani et al: Lip repositioning with or without myotomy: a systematic review. J Korean Assoc Oral Maxillofac Surg 2021 


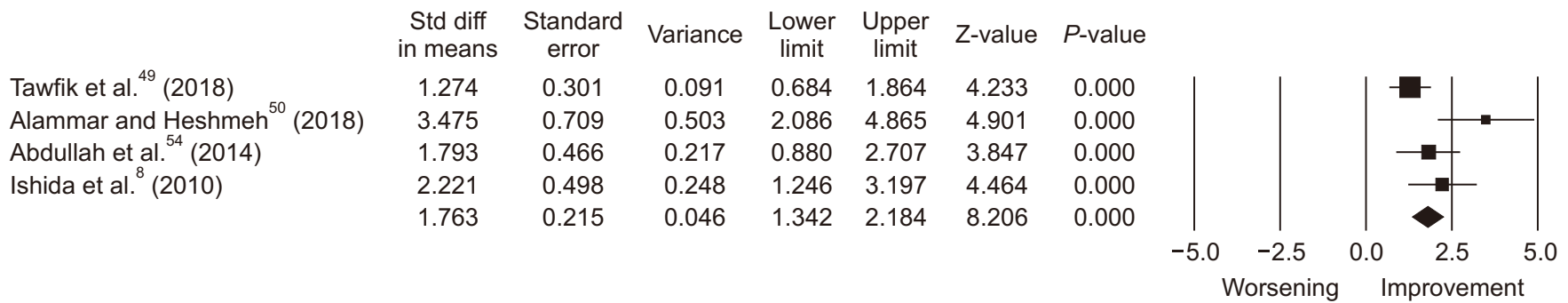

Fig. 3. Forest plot of effect size for lip repositioning with myotomy/muscle containment after 6 months. (Std diff: standard difference, Cl: confidence interval)

Mohammadreza Talebi Ardakani et al: Lip repositioning with or without myotomy: a systematic review. J Korean Assoc Oral Maxillofac Surg 2021

Study name

$\begin{array}{lccccccr} & \begin{array}{c}\text { Std diff } \\ \text { in means }\end{array} & \begin{array}{c}\text { Standard } \\ \text { error }\end{array} & \text { Variance } & \begin{array}{c}\text { Lower } \\ \text { limit }\end{array} & \begin{array}{c}\text { Upper } \\ \text { limit }\end{array} & \text { Z-value } & P \text {-value } \\ \text { Tawfik et al. }^{49}(2018) & 0.687 & 0.325 & 0.106 & 0.049 & 1.325 & 2.111 & 0.035 \\ \text { Alammar et al. }{ }^{51}(2018) & 1.395 & 0.475 & 0.226 & 0.463 & 2.327 & 2.934 & 0.003 \\ & 0.956 & 0.344 & 0.118 & 0.282 & 1.630 & 2.782 & 0.005\end{array}$

\section{Std diff in means and $95 \% \mathrm{Cl}$}

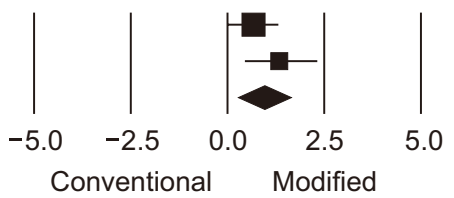

Fig. 4. Forest plot of effect size for comparative studies after 6 months. Conventional: Lip repositioning; Modified: Lip repositioning with myotomy/muscle containment. (Std diff: standard difference, Cl: confidence interval)

Mohammadreza Talebi Ardakani et al: Lip repositioning with or without myotomy: a systematic review. J Korean Assoc Oral Maxillofac Surg 2021

ing the efficacy of myotomy/muscle containment on outcome and long-term stability of lip repositioning surgery.

Most retrieved articles were case series or case reports. The ideal score for non-comparative studies according to MINORS scoring criteria is 16 , though none of the chosen studies obtained this. Therefore, the findings should be interpreted with caution.

Among 7 studies involving myotomy/muscle containment, 6 studies ${ }^{8,47,50-52,54}$ used additional modalities such as crown lengthening and frenectomy. Therefore, it is unclear how much of the improvement is related to lip repositioning surgery alone. One comparative study ${ }^{49}$ that evaluated the effect of myotomy without other interventions reported better results with the modified technique. However, they did not specify the etiologic contributors for gummy smile in their patients and concluded no clear correlation between etiology and achieved improvement. Studies reported various etiologies for their study population, limiting the ability to draw a conclusion, as vertical maxillary excess ${ }^{48,56,57}$ can compromise long-term stability ${ }^{15}$.

Some studies reported subjective improvement without an exact measurement of pre/postoperative gingival display $^{15,20,23,28,37,40}$. Success must be reported based on measurement of all parameters before and after the procedure to allow exact assessment of the improvement. Consequently, we included studies that reported pre- and postoperative measurements to assess treatment success more accurately. This also applies to patient-related outcome measures (PROMs). Therefore, standardization of the measurement protocol, techniques, outcomes, and PROMs is essential to draw meaningful conclusions.

Tawfik et al. ${ }^{62}$ published a systematic review in 2018, in which they concluded a persuasive need for randomized and comparative trials to assess the influence of different factors on outcomes, complications, and patient satisfaction. They carried out a randomized clinical trial ${ }^{49}$ to evaluate the effect of myotomy on lip repositioning results, reporting EGD reduction by $2.73 \pm 1.281 \mathrm{~mm}$ with classic lip repositioning and greater reduction of $3.57 \pm 1.62 \mathrm{~mm}$ with myotomy. In another study, Alammar et al. ${ }^{51}$ compared the conventional technique with the modified approach and demonstrated greater sustainability and less relapse in the modified surgical technique including myotomy. However, they conducted crown lengthening in addition to lip repositioning surgery, which must be considered when interpreting the results.

Based on the available data, lip repositioning can be a successful approach for EGD treatment in carefully selected cases, though it has been shown to have a higher chance of 
unfavorable results in cases of severe maxillary excess (EGD $>8 \mathrm{~mm})^{15}$. It seems that myotomy/muscle containment can result in better outcomes and stability of the achieved improvement. However, due to the limited number of studies and the discrepancy in the current evidence, further well-organized comparative clinical trials are needed to derive a conclusion regarding the effectiveness of myotomy/muscle containment compared with the conventional approach.

\section{ORCID}

Mohammadreza Talebi Ardakani, https://orcid.org/00000001-9997-3117

Anahita Moscowchi, https://orcid.org/0000-0003-13275014

Nasrin Keshavarz Valian, https://orcid.org/0000-00024218-5862

Elham Zakerzadeh, https://orcid.org/0000-0003-0860-4207

\section{Authors' Contributions}

M.T.A. participated in the study design and data synthesis. A.M. participated in data collection, performed the statistical analysis, and prepared the manuscript draft. N.K.V. and E.Z. participated in data collection. All authors read and approved the final manuscript.

\section{Conflict of Interest}

No potential conflict of interest relevant to this article was reported.

\section{References}

1. Tjan AH, Miller GD, The JG. Some esthetic factors in a smile. J Prosthet Dent 1984;51:24-8. https://doi.org/10.1016/s00223913(84)80097-9

2. Wu H, Lin J, Zhou L, Bai D. Classification and craniofacial features of gummy smile in adolescents. J Craniofac Surg 2010;21:1474-9. https://doi.org/10.1097/SCS.0b013e3181edc627

3. Miron H, Calderon S, Allon D. Upper lip changes and gingival exposure on smiling: vertical dimension analysis. Am J Orthod Dentofacial Orthop 2012;141:87-93. https://doi.org/10.1016/ j.ajodo.2011.07.017

4. Levine RA, McGuire M. The diagnosis and treatment of the gummy smile. Compend Contin Educ Dent 1997;18:757-62, 764; quiz 766.

5. Lee EA. Aesthetic crown lengthening: classification, biologic rationale, and treatment planning considerations. Pract Proced Aesthet Dent. 2004;16:769-78; quiz 780.

6. Kokich VG. Esthetics: the orthodontic-periodontic restorative connection. Semin Orthod 1996;2:21-30. https://doi.org/10.1016/ s1073-8746(96)80036-3

7. Hong RK, Lim SM, Heo JM, Baek SH. Orthodontic treatment of gummy smile by maxillary total intrusion with a midpalatal absolute anchorage system. Korean J Orthod 2013;43:147-58. https:// doi.org/10.4041/kjod.2013.43.3.147

8. Ishida LH, Ishida LC, Ishida J, Grynglas J, Alonso N, Ferreira MC. Myotomy of the levator labii superioris muscle and lip repositioning: a combined approach for the correction of gummy smile. Plast Reconstr Surg 2010;126:1014-9. https://doi.org/10.1097/ PRS.0b013e3181e3b6d4

9. Fowler P. Orthodontics and orthognathic surgery in the combined treatment of an excessively "gummy smile". N Z Dent J 1999;95:53-4.

10. Suber JS, Dinh TP, Prince MD, Smith PD. OnabotulinumtoxinA for the treatment of a "gummy smile". Aesthet Surg J 2014;34:4327. https://doi.org/10.1177/1090820X14527603

11. Rubinstein AM, Kostianovsky AS. Cosmetic surgery for the malformation of the laugh: original technique. Prensa Med Argent 1973;60:952.

12. Litton C, Fournier P. Simple surgical correction of the gummy smile. Plast Reconstr Surg 1979;63:372-3. https://doi. org/10.1097/00006534-197903000-00014

13. Ellenbogen R, Swara N. The improvement of the gummy smile using the implant spacer technique. Ann Plast Surg 1984;12:16-24. https://doi.org/10.1097/00000637-198401000-00004

14. Ezquerra F, Berrazueta MJ, Ruiz-Capillas A, Arregui JS. New approach to the gummy smile. Plast Reconstr Surg 1999;104:114350; discussion 1151-2.

15. Simon Z, Rosenblatt A, Dorfman W. Eliminating a gummy smile with surgical lip repositioning. J Cosmet Dent 2007;23:102-9.

16. Moher D, Liberati A, Tetzlaff J, Altman DG; PRISMA Group. Preferred reporting items for systematic reviews and meta-analyses: the PRISMA Statement. Open Med 2009;3:e123-30.

17. Harden A, Peersman G, Oliver S, Mauthner M, Oakley A. A systematic review of the effectiveness of health promotion interventions in the workplace. Occup Med (Lond) 1999;49:540-8. https:// doi.org/10.1093/occmed/49.8.540

18. Higgins JPT, Thomas J, Chandler J, Cumpston M, Li T, Page MJ, et al., eds. Cochrane handbook for systematic reviews of interventions. 2nd ed. Chichester: John Wiley \& Sons; 2019.

19. Slim K, Nini E, Forestier D, Kwiatkowski F, Panis Y, Chipponi J. Methodological index for non-randomized studies (MINORS): development and validation of a new instrument. ANZ J Surg 2003;73:712-6. https://doi.org/10.1046/j.1445-2197.2003.02748.x

20. Ramesh A, Vellayappan R, Ravi S, Gurumoorthy K. Esthetic lip repositioning: a cosmetic approach for correction of gummy smile a case series. J Indian Soc Periodontol 2019;23:290-4. https://doi. org/10.4103/jisp.jisp_548_18

21. Foudah MA. Lip repositioning: an alternative to invasive surgery a 4 year follow up case report. Saudi Dent J 2019;31(Suppl):S78-84. https://doi.org/10.1016/j.sdentj.2019.02.030

22. K D, Yadalam U, Ranjan R, Narayan SJ. Lip repositioning, an alternative treatment of gummy smile - a case report. J Oral Biol Craniofac Res 2018;8:231-3. https://doi.org/10.1016/ j.jobcr.2017.09.007

23. Faus-Matoses V, Faus-Matoses I, Jorques-Zafrilla A, Faus-Llácer VJ. Lip repositioning technique. A simple surgical procedure to improve the smile harmony. J Clin Exp Dent 2018;10:e408-12. https://doi.org/10.4317/jced.54721

24. Sharma A, Sharma S, Garg H, Singhal V, Mishra P. Lip repositioning: a boon in smile enhancement. J Cutan Aesthet Surg 2017;10:219-22. https://doi.org/10.4103/JCAS.JCAS_50_17

25. Sánchez IM, Gaud-Quintana S, Stern JK. Modified lip repositioning with esthetic crown lengthening: a combined approach to treating excessive gingival display. Int J Periodontics Restorative Dent 2017;37:e130-4. https://doi.org/10.11607/prd.3124 
26. Littuma GJS, de Souza HCM, Peñarrieta GM, Magini RS, SabaChujfi E. Lip repositioning technique with smile elevator muscle containment - a novel cosmetic approach for gummy smile: case report. Compend Contin Educ Dent 2017;38:e9-12.

27. Khan MN, Akbar Z, Shah I. Rapid and promising technique to treat gummy smile - lip repositioning. J Coll Physicians Surg Pak 2017;27:447-9.

28. Gibson MP, Tatakis DN. Treatment of gummy smile of multifactorial etiology: a case report. Clin Adv Periodontics 2017;7:167-73. https://doi.org/10.1902/cap.2017.160074

29. Farista S, Yeltiwar R, Kalakonda B, Thakare KS. Laser-assisted lip repositioning surgery: novel approach to treat gummy smile. J Indian Soc Periodontol 2017;21:164-8. https://doi.org/10.4103/jisp. jisp_411_16

30. Mahn DH. Elimination of a "gummy smile" with crown lengthening and lip repositioning. Compend Contin Educ Dent 2016;37:525.

31. Aly LA, Hammouda NI. Botox as an adjunct to lip repositioning for the management of excessive gingival display in the presence of hypermobility of upper lip and vertical maxillary excess. Dent Res J (Isfahan) 2016;13:478-83. https://doi.org/10.4103/17353327.197039

32. Rao AG, Koganti VP, Prabhakar AK, Soni S. Modified lip repositioning: a surgical approach to treat the gummy smile. J Indian Soc Periodontol 2015;19:356-9. https://doi.org/10.4103/0972124X.152400

33. Muthukumar S, Natarajan S, Madhankumar S, Sampathkumar J. Lip repositioning surgery for correction of excessive gingival display. J Pharm Bioallied Sci 2015;7(Suppl 2):S794-6. https://doi. org/10.4103/0975-7406.163567

34. Bhola M, Fairbairn PJ, Kolhatkar S, Chu SJ, Morris T, de Campos M. LipStaT: The lip stabilization technique- indications and guidelines for case selection and classification of excessive gingival display. Int J Periodontics Restorative Dent 2015;35:549-59. https:// doi.org/10.11607/prd.2059

35. Storrer CL, Valverde FK, Santos FR, Deliberador TM. Treatment of gummy smile: gingival recontouring with the containment of the elevator muscle of the upper lip and wing of nose. A surgery innovation technique. J Indian Soc Periodontol 2014;18:656-60. https:// doi.org/10.4103/0972-124X.142468

36. Grover HS, Gupta A, Luthra S. Lip repositioning surgery: a pioneering technique for perio-esthetics. Contemp Clin Dent 2014;5:142-5. https://doi.org/10.4103/0976-237X.128697

37. Gaddale R, Desai SR, Mudda JA, Karthikeyan I. Lip repositioning. J Indian Soc Periodontol 2014;18:254-8. https://doi. org/10.4103/0972-124X.131349

38. Sheth T, Shah $\mathrm{S}$, Shah M, Shah E. Lip reposition surgery: a new call in periodontics. Contemp Clin Dent 2013;4:378-81. https://doi. org/10.4103/0976-237X.118353

39. Humayun N, Kolhatkar S, Souiyas J, Bhola M. Mucosal coronally positioned flap for the management of excessive gingival display in the presence of hypermobility of the upper lip and vertical maxillary excess: a case report. J Periodontol 2010;81:1858-63. https:// doi.org/10.1902/jop.2010.100292

40. Gupta KK, Srivastava A, Singhal R, Srivastava S. An innovative cosmetic technique called lip repositioning. J Indian Soc Periodontol 2010;14:266-9. https://doi.org/10.4103/0972-124X.76936

41. Rosenblatt A, Simon Z. Lip repositioning for reduction of excessive gingival display: a clinical report. Int J Periodontics Restorative Dent 2006;26:433-7.

42. Ambrosio F, Gadalla H, Kapoor N, Neely AL, Kinaia BM. Surgical lip repositioning procedure to correct excessive gingival display: a case report of identical twins. Clin Adv Periodontics 2018;8:48-53. https://doi.org/10.1902/cap.2017.170037

43. Assenza B, Carinci F, Di Cristinzi A, Sinjari B, Murmura G, Scarano A. A cosmetic technique called lip repositioning in a patient of excessive gingival display. Eur J Inflamm 2011;9:115-9.
44. Ergezen E, Akkocaoğlu M, Avağ C. Treatment of excessive gingival display with lip repositioning technique. Int J Oral Maxillofac Surg 2017;46(Suppl 1):367. https://doi.org/10.1016/ j.ijom.2017.02.1236

45. Mangano A, Mangano A. An innovative cosmetic technique called lip repositioning: a less invasive treatment possibility for dentists and surgeons. J Indian Soc Periodontol 2013;17:287. https://doi. org/10.4103/0972-124X.115635

46. Polo M. Myotomy of the levator labii superioris muscle and lip repositioning: a combined approach for the correction of gummy smile. Plast Reconstr Surg 2011;127:2121-2. https://doi. org/10.1097/PRS.0b013e31820e930a

47. Ganesh B, Burnice NKC, Mahendra J, Vijayalakshmi R, K AK. Laser-assisted lip repositioning with smile elevator muscle containment and crown lengthening for gummy smile: a case report. Clin Adv Periodontics 2019;9:135-41. https://doi.org/10.1002/ cap. 10060

48. Torabi A, Najafi B, Drew HJ, Cappetta EG. Lip repositioning with vestibular shallowing technique for treatment of excessive gingival display with various etiologies. Int J Periodontics Restorative Dent 2018;38(Suppl):e1-8. https://doi.org/10.11607/prd.3120

49. Tawfik OK, Naiem SN, Tawfik LK, Yussif N, Meghil MM, Cutler $\mathrm{CW}$, et al. Lip repositioning with or without myotomy: a randomized clinical trial. J Periodontol 2018;89:815-23. https://doi. org/10.1002/JPER.17-0598

50. Alammar AM, Heshmeh OA. Lip repositioning with a myotomy of the elevator muscles for the management of a gummy smile. Dent Med Probl 2018;55:241-6. https://doi.org/10.17219/dmp/92317

51. Alammar A, Heshmeh O, Mounajjed R, Goodson M, Hamadah $\mathrm{O}$. A comparison between modified and conventional surgical techniques for surgical lip repositioning in the management of the gummy smile. J Esthet Restor Dent 2018;30:523-31. https://doi. org/10.1111/jerd.12433

52. Storrer CLM, de Oliveira ND, Deliberador TM, Ori LT, Guerrero SM, Santos FR, et al. Treatment of gingival smile: a case report. J Int Acad Periodontol 2017;19:51-6.

53. Mantovani MB, Souza EC, Marson FC, Corrêa GO, Progiante PS, Silva CO. Use of modified lip repositioning technique associated with esthetic crown lengthening for treatment of excessive gingival display: a case report of multiple etiologies. J Indian Soc Periodontol 2016;20:82-7. https://doi.org/10.4103/0972-124X.164746

54. Abdullah WA, Khalil HS, Alhindi MM, Marzook H. Modifying gummy smile: a minimally invasive approach. J Contemp Dent Pract 2014;15:821-6. https://doi.org/10.5005/jp-journals-10024-1625

55. Ozturan S, Ay E, Sagir S. Case series of laser-assisted treatment of excessive gingival display: an alternative treatment. Photomed Laser Surg 2014;32:517-23. https://doi.org/10.1089/pho.2014.3737

56. Jananni M, Sivaramakrishnan M, Libby TJ. Surgical correction of excessive gingival display in class I vertical maxillary excess: $\mathrm{Mu}-$ cosal strip technique. J Nat Sci Biol Med 2014;5:494-8. https://doi. org/10.4103/0976-9668.136290

57. Gabrić Pandurić D, Blašković M, Brozović J, Sušić M. Surgical treatment of excessive gingival display using lip repositioning technique and laser gingivectomy as an alternative to orthognathic surgery. J Oral Maxillofac Surg 2014;72:404.e1-11. https://doi. org/10.1016/j.joms.2013.10.016

58. Dayakar MM, Gupta S, Shivananda H. Lip repositioning: an alternative cosmetic treatment for gummy smile. J Indian Soc Periodontol 2014;18:520-3. https://doi.org/10.4103/0972-124X.138751

59. Silva CO, Ribeiro-Júnior NV, Campos TV, Rodrigues JG, Tatakis DN. Excessive gingival display: treatment by a modified lip repositioning technique. J Clin Periodontol 2013;40:260-5. https://doi. org/10.1111/jcpe. 12046

60. Ribeiro-Júnior NV, Campos TV, Rodrigues JG, Martins TM, Silva CO. Treatment of excessive gingival display using a modified lip repositioning technique. Int J Periodontics Restorative Dent 
2013;33:309-14. https://doi.org/10.11607/prd.1325

61. Jacobs PJ, Jacobs BP. Lip repositioning with reversible trial for the management of excessive gingival display: a case series. Int J Periodontics Restorative Dent 2013;33:169-75. https://doi. org $/ 10.11607 /$ prd. 1483

62. Tawfik OK, El-Nahass HE, Shipman P, Looney SW, Cutler CW, Brunner M. Lip repositioning for the treatment of excess gingival display: a systematic review. J Esthet Restor Dent 2018;30:101-12. https://doi.org/10.1111/jerd.12352
How to cite this article: Ardakani MT, Moscowchi A, Valian NK, Zakerzadeh E. Lip repositioning with or without myotomy: a systematic review. J Korean Assoc Oral Maxillofac Surg 2021;47:314. https://doi.org/10.5125/jkaoms.2021.47.1.3 